\title{
EFFECT OF USING SOME MEDICINAL PLANTS AND THEIR MIXTURE ON PRODUCTIVE AND REPRODUCTIVE PERFORMANCE OF GIMMIZAH STRAIN 1- GROWTH PERFORMANCE
}

Abdalla, A. A.; Mona A. Mahmoud, O.M. Aly; and Effat.Y.Sherif. El-Sabahia Poult. Res. Station., Animal Prod. Res. Inst., Agr. Res. Center, Minis. of Agri., Egypt. monamorsy2003@yahoo.com

\begin{abstract}
This investigation was designed to evaluate the feed additive potential and antibacterial effect of some medicinal plants as fenugreek, cinnamon, fennel and anise. A total of 405 unsexed Gimmizah chicks (4 weeks of age) were randomly assigned to nine treatment groups, three replicates (each contained 15 chicks). All chicks were raised in battery brooder placed in a temperature-controlled room until 16 wks of age. Chicks in 1, 2, 3 and 4 treatments were fed basal diet supplemented with $1 \mathrm{~g}$ fenugreek, cinnamon, fennel and anise $/ \mathrm{kg}$ of diet, respectively. Chicks in treatments 5, 6, 7 and 8 were fed basal diet supplemented with $0.5,1.0,1.5$ and $2.0 \mathrm{~g}$ of equal mixture from the previous medicinal plants $/ \mathrm{kg}$ diet, respectively. The last group of treatment was used as a control and fed basal diet without any supplementation (T9).

Body weight and body weight gain for birds fed basal diet supplemented with $1 \mathrm{~g}$ fenugreek $/ \mathrm{kg}$ diet (T1) at 16 weeks of age had increased significantly by 24.0 and $26.0 \%$, respectively, than control group (T9), and they also increased significantly $(\mathrm{P}<0.05)$ by 9.03 and $10.0 \%$, respectively, than the chicks fed $2.0 \mathrm{~g} / \mathrm{Kg}$ of equal mixture (T8). Supplementation of fenugreek alone (T1) increased significantly feed intake through the experimental period ( $80.63 \mathrm{~g} / \mathrm{chick} /$ day) as compared to the other treatments. The best feed conversion was recorded $(4.23 \mathrm{~g} / \mathrm{kg}$ diet) for the chicks fed basal diet supplemented with $2.0 \mathrm{~g} / \mathrm{kg}$ of equal mixture medicinal plants (T8), while the worst was recorded for the chicks in control group (T9). Supplementation of fenugreek alone (T1) and the mixture at $2.0 \mathrm{~g} / \mathrm{Kg}$ (T8) increased significantly the absolute carcass weight and its percentage $(1082.9 \mathrm{~g}$ and $70.87 \%$ for $\mathrm{T} 1$ and $1014.4 \mathrm{~g}$ and $72.38 \%$ for T8) as compared to the other treatments. However, there were no significant differences among the percentage of cocks gizzard, liver, spleen and testes weight due to the different treatments Total cholesterol and the level of Alanine transaminase in blood plasma decreased significantly with supplementation of medicinal plants which studied alone or in the mixture form compared to control group. The total of aerobic and anaerobic bacterial counts and the counts of total coliform were decreased due to supplementation of the basal diet with medicinal plants as compared to control (T9). The greatest reduction of bacterial count was observed with the chicks fed the basal diet supplemented by medicinal plants in a mixture form. Liver, jejunum and ileum DNA concentration were significantly greater for both chicks groups fed basal diet supplemented with fenugreek (T1) or with $2.0 \mathrm{~g}$ of mixture/kg diet (T8) than the other treatments. The lowest liver, jejunum and ileum DNA concentration was detected for control group (T9). Supplementation of medicinal plants studied either individual or in a mixture form to the basal diet increased the economical efficiency (EE). Generally, the best EE was recorded for the chicks fed basal diet supplemented with medicinal plants in a mixture form at levels $2 \mathrm{~g} / \mathrm{Kg}$ (T8) and $1.5 \mathrm{~g} / \mathrm{Kg}$ (T7) $(0.375,0.296$, respectively).
\end{abstract}


Abdalla, A. A. et al.

\section{INTRODUCTION}

Recently, it has been found that the natural additives such as herbs and edible plants have some properties as growth enhancers to replace synthetic drugs. These additives are given to animals or birds to improve their physiological and productive performance under normal or stress conditions. Bans and restrictions on the use of animal antibiotic growth promoters stimulated interest in bioactive secondary metabolites of plant source as alternative performance enhancers (Greathead, 2003). Herbs contain some complicated mixtures of organic chemicals that may vary depending upon many factors related to the growth, production, and processing of the herbal product. Though herbs with antimicrobial properties are reported, their use in poultry diets has not been studied extensively.

Fenugreek (Trigonella foenum graecum L.) is an annual plant from the family of leguminous. It been recognized as a potential source of diosgenin a basic compound in the hemisynthesis of steroidal sapogenins such as cortisone and sex hormones (Mazur et al. 1998). Rao and Sharma (1987) found that the seeds of fenugreek contained $4.8 \%$ saponins. Fenugreek seeds are considered as an appetizer and helps in digestion. Fenugreek has antioxidant, antifungal, antiviral and anticarcinogenic activities (Mazur et al. 1998). The use of fenugreek was reported to improve the feed intake, feed efficiency, health and immunity in poultry (El-Mallah et al. 2005 and Abaza, 2007).

Cinnamon (Cinnamomum cassia), candies and gums have minimum inhibitory concentrations ranging from $25-100 \mathrm{mg} / \mathrm{ml}$ (Quale et al. 1996). Essential oils of cinnamon were found to possess antimicrobial properties in-vitro and shown to inhibit the growth of B.cereus (Valero and Salmeron, 2003). Hassan et al. (2004) observed that there were no significant difference in growth treats, while, feed conversion was significantly improved by cinnamon supplementation. Also, albumin content, serum total lipids and cholesterol were significantly decreased by cinnamon supplementation. In a $21 \mathrm{~d}$ feeding trail, the high level or low level of cinnamon extract had no significant effect on broilers growth traits (Mohan, 2004).

Fennel has been used as estrogenic agents and increase libido (Negussie, 1989). A majority of spices (fennel) enhanced the activity of pancreatic lipase and amylase when they are directly in contact with the enzyme (Rao et al., 1996). Adding fennel to the control diet improved growth traits (Tolba, 2003) in broiler , (Abd El-Latif et al., 2002) in Japanese quail and the results of Ghazalah et al., 1996 how used fennel oil in duck diets. The greatest percent of dressing, abdominal fat and edible giblets were obtained from birds fed dietary fennel in Japanese quail (Abd El-Latif, et al., 2002).

Anise (Pimpinella anisum) has been used as a traditional aromatic herb in many drinks and baked foods because of the presence of volatile oils in its fruits commonly known as seeds. Hot water extracts of the seeds have been used also in folk medicine for their diuretic and laxative effect, expectorant and anti-spasmodic action, and their ability to ease intestinal colic and flatulence (Kreydiyyeh et al., 2003 and Kosalec et al., 2005). Also, Anise promoted the absorption of iron (El-Shobaki et al., 1990). 
Large body size has been found to be positively correlated with increased numbers of muscle cells (Smith, 1963; Lepore et al., 1965). DNA concentration is association with genetic increases in BW (Lepore et al., 1965 and Fowler et al., 1980). Palo et al. (1995) found that total DNA of livers and jejunums were determined as indices of changes in cell size and number, also they reported that reduction of liver and jejunum cell number decrease total organ DNA.

The following study was conducted to investigate the effect of using fenugreek, cinnamon, fennel and anise as medicinal plants on productive performance, blood constitutes and DNA concentration of Gimmizah chicken strain.

\section{MATERIAL AND METHODS}

This study was carried out at El-Sabahia Poultry Research Station, Animal Production Research Institute, Agriculture Research Center. At 4 weeks of age, 405 unsexed Gimmizah chicks were wing-banded, weighed and randomly allocated to similar 9 treatment groups (three replicates each contained 15 chicks). All chicks were raised in battery brooder and placed in a temperature-controlled room. Feed and water were offered for ad-libtum through the experimental periods. Corn-Soy experimental diets were used as a basal diet through the experimental periods from 4 to 16 weeks of age (Table 1). Chicks within each treatment were fed as follows:

- Basal diet + Fenugreek powder $(1 \mathrm{~g} / \mathrm{Kg})$. (T1)

- Basal diet + cinnamon powder $(1 \mathrm{~g} / \mathrm{Kg})$. (T2)

- Basal diet + fennel powder $(1 \mathrm{~g} / \mathrm{Kg})$. (T3)

- Basal diet + anise powder $(1 \mathrm{~g} / \mathrm{Kg})$. (T4)

- Basal diet + equal mixture of the previous additives $(0.5 \mathrm{~g} / \mathrm{Kg})$. (T5)

- Basal diet + equal mixture of the previous additives $(1.0 \mathrm{~g} / \mathrm{Kg})$. (T6)

- Basal diet + equal mixture of the previous additives $(1.5 \mathrm{~g} / \mathrm{Kg})$. (T7)

- Basal diet + equal mixture of the previous additives $(2.0 \mathrm{~g} / \mathrm{Kg})$. (T8)

- Fed basal diet without any supplementation (control). (T9)

Table (1): Composition and calculated analysis of the basal diets during the experimental period.

\begin{tabular}{|c|c|c|c|c|c|}
\hline \multirow[t]{2}{*}{ Ingredients (\%) } & \multirow{2}{*}{$\begin{array}{c}\text { Starter } \\
(0-8 \text { wks })\end{array}$} & \multirow{2}{*}{$\begin{array}{c}\text { Grower } \\
\text { (8-16 wks) }\end{array}$} & \multicolumn{3}{|c|}{$\begin{array}{c}\text { Calculated analysis } \\
\text { (according to NRC,1994) }\end{array}$} \\
\hline & & & Chemical components & $\begin{array}{c}\text { Starter } \\
\text { (0-8 wks) }\end{array}$ & $\begin{array}{c}\text { Grower } \\
(8-16 \text { wks })\end{array}$ \\
\hline Yellow corn & 64.00 & 63.00 & Crude protein (\%) & 19.56 & 15.56 \\
\hline Soybean meal $(44 \% \mathrm{CP})$ & 32.10 & 17.60 & ME (Kcal/kg diet) & 2860 & 2707 \\
\hline Wheat bran & ------ & 15.68 & C/P ratio & 146 & 174 \\
\hline Dicalcium phosphate & 1.80 & 1.25 & Ether extract (\%) & 2.69 & 3.01 \\
\hline Limestone & 1.40 & 1.80 & Crude fiber (\%) & 3.65 & 4.34 \\
\hline Methionine & 0.10 & 0.07 & Calcium (\%) & 1.03 & 0.97 \\
\hline $\mathrm{NaCl}$ & 0.30 & 0.30 & Phosphorus available (\%) & 0.47 & 0.39 \\
\hline Vit.+mineral (premix) ${ }^{1}$ & 0.30 & 0.30 & Methionine (\%) & 0.41 & 0.33 \\
\hline \multirow[t]{2}{*}{ Total } & 100 & 100 & Methionine+Cysteine (\%) & 0.74 & 0.54 \\
\hline & & & Lysine (\%) & & \\
\hline Total price (LE) & 1590 & 1431 & & 1.03 & 0.73 \\
\hline
\end{tabular}

${ }^{1}$ Three kg of vitamin- mineral premix per ton of feed supplied each $\mathrm{kg}$ of diet with Vit. A 12000 IU; Vit. D 2000 IU; Vit. E. 10mg; Vit. k3 2mg; Vit.B $B_{1}$ 1mg; Vit. $B_{2} 4 \mathrm{mg}$; Vit. B 1.5 mg; Pantothenic acid 10mg; Vit. $B_{12} 0.01 \mathrm{mg}$; Folic acid 1mg; Niacin 20mg; Biotin $0.05 \mathrm{mg}$; Choline chloride (50\% choline) $500 \mathrm{mg}$; Zn 55mg; Fe 30mg; I 1mg; Se 0.1mg; Mn 55mg; ethoxyqain 3000 mg. 
Abdalla, A. A. et al.

Body weight (BW) and feed consumption (FI) were recorded at 4 weeks (wks) of age and at the end of experimental (16 wks of age). Body weight gain (BWG) and feed conversion (FC) were estimated during the same previous periods.

Individual blood samples were taken from jugular vein of 3 birds within each treatment at 16 weeks of ages. Serum was separated for determination cholesterol, total protein, albumin, globulin, Alanine transaminase (ALT) and Aspartate transaminase (AST) were calorimetrically determined using commercial kits, following the same steps as described by manufactures. Wintrobe hematocrit tubes were used for determination of hematocrit value $(\mathrm{HV})$. Hemoglobin $(\mathrm{Hg})$ concentration was determined by the cyanomethemoglobin procedure (Eilers, 1967). Red blood cells (RBCs) were counted on an $\mathrm{AO}$ Bright line hemocytometer using a light microscope at 400x magnification (Seiverd, 1964).

At 16 weeks of age five cocks from each treatment were selected randomly and slaughtered for carcass evaluation. Carcass was eviscerated and head and shank were removed, liver, gizzard, spleen and testes were dissected from the viscera and weighed. Each portion was expressed as a percentage of life body weight.

Total DNA of intestinal parts (duodenum, jejunum and ileum) and liver were extracted using the procedure of Shibko et al, (1967), whereas DNA concentration was quantified using the method of Burton (1968).

Intestinal aerobic and anaerobic microflora counts were determined. Aerobic plate count (APC), total coliform count and total anaerobic count were carried out according to American Public Health Association (A.P.H.A) (1985). Serial ten fold dilutions were done on standard plate count agar, Bacto MacConkeys's broth (Difco) and anaerobic agar medium respectively.

Economical efficiency $(E E)$ of the experimental diets was calculated according to input-output analysis at the end of the experiment (Hassan et al., 1996).

All results were statistically analyzed by General Linear Models (GLM), one way analysis of variance, using SAS software (SAS Institute, 1990). Differences among means were separated using Duncan's multiple range test (Duncan, 1955).

\section{RESULTS AND DISCUSSION}

\section{1- Body weight and body weight gain:-}

Significant differences among treatments were found for BW and BWG through the experimental period (Table 2). The BW and BWG for the birds fed basal diet supplemented with $1 \mathrm{~g}$ fenugreek $/ \mathrm{kg}$ diet (T1) was significantly superior and had the heaviest BW and BWG than the others through the experimental period. Birds BW fed $2.0 \mathrm{~g}$ mixture $/ \mathrm{Kg}$ diet (T8) significantly decreased than those fed basal diet supplemented with $1 \mathrm{~g}$ fenugreek /Kg diet (T1). However, BW of birds fed the other supplementation (T2, T3, T4, T5, T6 and T7) was significantly decreased compared to BW of birds for T1 and T8 groups. Moreover, the lightest BW was recorded with chicks in control group (T9). Birds BW and BWG of T1 group at 16 weeks of 
age (the end of experiment) had increased significantly by 24.0 and $26.0 \%$, respectively, than control group (T9).

Table (2): Effect of different medicinal plants supplementations on chicks body weight, body weight gain (g), feed consumption (g/chick/day) and feed conversion ( $\mathrm{g}$ feed/g gain).

\begin{tabular}{|c|c|c|c|c|c|}
\hline \multirow{2}{*}{$\begin{array}{c}\text { Dietary } \\
\text { supplementations }\end{array}$} & \multicolumn{2}{|c|}{$\begin{array}{c}\text { Body weight } \\
\text { (g) }\end{array}$} & $\begin{array}{c}\text { Body weight } \\
\text { gain (g) }\end{array}$ & $\begin{array}{c}\text { Feed } \\
\text { consumption } \\
\text { (g/chick/day) }\end{array}$ & $\begin{array}{c}\text { Feed } \\
\text { conversion }\end{array}$ \\
\cline { 2 - 6 } & $\mathbf{4} \mathbf{~ w k}$ & $\mathbf{1 6} \mathbf{w k}$ & $\mathbf{4 - 1 6} \mathbf{w k}$ & $\mathbf{4 - 1 6} \mathbf{w k}$ & $\mathbf{4 - 1 6} \mathbf{w k}$ \\
\hline T1 & $116.33 \pm 4.56$ & $1527.94 \pm 37.01^{\mathrm{a}}$ & $1411.61 \pm 31.01^{\mathrm{a}}$ & $80.63 \pm 11.32^{\mathrm{a}}$ & $4.80 \pm 0.12^{\mathrm{bc}}$ \\
\hline T2 & $118.54 \pm 4.45$ & $1346.36 \pm 19.63^{\mathrm{c}}$ & $1227.82 \pm 14.04^{\mathrm{c}}$ & $71.71 \pm 9.92^{\mathrm{b}}$ & $4.91 \pm 0.23^{\mathrm{b}}$ \\
\hline T3 & $119.20 \pm 5.73$ & $1335.11 \pm 34.31^{\mathrm{c}}$ & $1215.91 \pm 20.00^{\mathrm{c}}$ & $71.46 \pm 11.00^{\mathrm{b}}$ & $4.94 \pm 0.15^{\mathrm{b}}$ \\
\hline T4 & $116.30 \pm 3.70$ & $1334.44 \pm 31.21^{\mathrm{c}}$ & $1218.14 \pm 14.44^{\mathrm{c}}$ & $72.67 \pm 10.32^{\mathrm{b}}$ & $5.01 \pm 0.25^{\mathrm{b}}$ \\
\hline T5 & $115.07 \pm 5.52$ & $1238.30 \pm 54.12^{\mathrm{d}}$ & $1123.23 \pm 30.57^{\mathrm{d}}$ & $64.16 \pm 10.02^{\mathrm{c}}$ & $4.80 \pm 0.43^{\mathrm{bc}}$ \\
\hline T6 & $113.36 \pm 7.84$ & $1311.28 \pm 33.01^{\mathrm{c}}$ & $1197.92 \pm 20.01^{\mathrm{c}}$ & $67.09 \pm 11.00^{\mathrm{c}}$ & $4.70 \pm 0.35^{\mathrm{c}}$ \\
\hline T7 & $116.93 \pm 5.63$ & $1333.72 \pm 37.01^{\mathrm{c}}$ & $1216.79 \pm 22.01^{\mathrm{c}}$ & $69.26 \pm 9.94^{\mathrm{c}}$ & $4.78 \pm 0.28^{\mathrm{bc}}$ \\
\hline T8 & $117.13 \pm 4.02$ & $1401.44 \pm 34.33^{\mathrm{b}}$ & $1284.31 \pm 19.33^{\mathrm{b}}$ & $64.66 \pm 8.11^{\mathrm{c}}$ & $4.23 \pm 0.23^{\mathrm{d}}$ \\
\hline T9 & $114.40 \pm 5.67$ & $1236.54 \pm 43.81^{\mathrm{d}}$ & $1122.14 \pm 25.04^{\mathrm{d}}$ & $72.43 \pm 9.95^{\mathrm{b}}$ & $5.42 \pm 0.29^{\mathrm{a}}$ \\
\hline
\end{tabular}

\& Column means with different superscripts are differ significantly $(P<0.05)$.

(T1) Basal diet + Fenugreek powder $(1 \mathrm{~g} / \mathrm{Kg})$, (T2) basal diet + cinnamon powder $(1 \mathrm{~g} / \mathrm{Kg})$ (T3) basal diet + fennel powder (1 g/Kg), (T4) basal diet + anise powder (1 g/Kg), (T5) basal diet + equal mixture of the previous additives $(0.5 \mathrm{~g} / \mathrm{Kg})$. (T6) basal diet + equal mixture of the previous additives $(1.0 \mathrm{~g} / \mathrm{Kg})$, (T7) basal diet + equal mixture of the previous additives $(1.5 \mathrm{~g} / \mathrm{Kg})$, (T8) basal diet + equal mixture of the previous additives $(2.0 \mathrm{~g} / \mathrm{Kg})$ and $(\mathrm{T9}) \mathrm{fed}$ basal diet without any supplementation (control).

Also, they had increased significantly by 9.03 and $10.0 \%$, respectively than those of T8. These results agree with reports of many investigators, who reported that adding fennel to the control diet improved body weight and gain weight (Tolba, 2003) in broiler and (Abd El-Latif et al., 2002) in Japanese quail and the results of Ghazalah et al. (1996) how used fennel oil in duck diets. In addition, Ramakrishna et al. (2003) reported that a majority of fenugreek enhanced the activity of pancreatic lipase and amylase when they are directly in contact with the enzyme. Birds fed on $1 \%$ grounds of dried thyme or fennel increased live body weight, weight gain under normal or high temperature conditions compared to those fed on un-supplemented control diets at 42 or 49 days of age (Tolba, 2003). On the other hand, Hassan et al. (2004) and Mohan, (2004) observed that there was no significant difference in body weight and body weight gain by cinnamon supplementation.

\section{2-Feed intake and feed conversion ratio:-}

Statistically analysis of feed intake in Table 2, indicates that, FI was significantly $(\mathrm{P}<0.05)$ affected by different supplementation levels through the experimental period. Generally, supplementation of fenugreek alone (T1) increased significantly the birds FI through all experimental period compared to the other supplementations. This result reflects that incorporation fenugreek in birds diet was satisfactory and had no palatability problems during the present experiment. Also, the lowest FI (64.16 g/ birds /day) was recorded for the chicks fed basal diet supplemented with $0.5 \mathrm{~g}$ mixture $/ \mathrm{Kg}$ diet (T5). However, birds fed basal diets supplemented with 0.5, 1.0, 1.5 and $2.0 \mathrm{~g}$ mixture/ $\mathrm{Kg}$ (T5, T6, T7 and T8) were significantly decreased in the FI 
Abdalla, A. A. et al.

compared to the control. On the other hand diets supplemented with cinnamon, fennel and anise did not improve feed intake than the control diet.

Results in Table 2, indicate that feed FC was significantly affected by different levels supplementation through the experimental period. The best FC was recorded for the birds supplemented with $2.0 \mathrm{~g}$ mixture $/ \mathrm{Kg}$ diet (4.23), while the worst one was recorded for control group (5.42). Hassan et al. (2004) observed that there were no significant effect on feed intake while, feed conversion was significantly improved by cinnamon supplementation. In contrary, Mohan (2004) reported that there was no difference in feed efficiency was observed with the cinnamon extracts except low level which reduced feed efficiency compared to the other treatments. Adding fennel to the control diet improved feed intake and feed conversion (Tolba, 2003) in broiler, (Abd El-Latif et al. 2002) in Japanese quail. Also, the same results were reported by and adding fennel oil to duck diets (Ghazalah et al. 1996). The use of fenugreek was reported to improve the feed intake, feed efficiency, health and immunity in poultry (El-Mallah et al. 2005 and Abaza, 2007).

3-Carcass characteristics:-

Medical plants supplementation and their mixture affected significantly carcass weight and carcass percentage (Table 3 ).

Table (3): Effect of different medicinal plants supplementations on carcass weight and the percentages of some carcass traits.

\begin{tabular}{|c|c|c|c|c|c|c|}
\hline \multirow{2}{*}{$\begin{array}{c}\text { Feed } \\
\text { supplementation }\end{array}$} & \multirow{2}{*}{$\begin{array}{c}\text { Carcass } \\
\text { weight }(\mathbf{g})\end{array}$} & \multicolumn{5}{|c|}{ Carcass traits \% } \\
\cline { 3 - 7 } & $1082.9 \pm 31.5^{\mathrm{a}}$ & $70.87 \pm 87.3^{\mathrm{a}}$ & $1.65 \pm .4$ & $1.92 \pm 0.19$ & $0.29 \pm 0.03$ & $1.6 .8 \pm 0.18$ \\
\hline T1 & $831.1 \pm 15.9^{\mathrm{c}}$ & $61.73 \pm 2.88^{\mathrm{c}}$ & $1.65 \pm 0.9$ & $1.91 \pm 0.12$ & $0.34 \pm 0.08$ & $1.67 \pm 0.05$ \\
\hline T2 & $861.8 \pm 12.6^{\mathrm{c}}$ & $64.55 \pm 1.97^{\mathrm{c}}$ & $1.99 \pm 0.6$ & $2.16 \pm 0.12$ & $0.29 \pm 0.06$ & $1.72 \pm 0.12$ \\
\hline T3 & $849.5 \pm 22.4^{\mathrm{c}}$ & $63.66 \pm 3.64^{\mathrm{c}}$ & $1.71 \pm 0.8$ & $1.99 \pm 0.12$ & $0.28 \pm 0.12$ & $1.65 \pm 0.14$ \\
\hline T4 & $822.6 \pm 15.5^{\mathrm{c}}$ & $66.43 \pm 1.95^{\mathrm{b}}$ & $1.69 \pm 0.7$ & $1.98 \pm 0.13$ & $0.27 \pm 0.04$ & $1.72 \pm 0.16$ \\
\hline T5 & $895.6 \pm 18.7^{\mathrm{c}}$ & $68.28 \pm 2.81^{\mathrm{b}}$ & $1.62 \pm 0.7$ & $2.31 \pm 0.19$ & $0.30 \pm 0.11$ & $1.74 \pm 0.24$ \\
\hline T6 & $903.4 \pm 15.3^{\mathrm{c}}$ & $67.73 \pm 2.12^{\mathrm{b}}$ & $1.84 \pm 0.4$ & $2.36 \pm 0.18$ & $0.21 \pm 0.06$ & $1.68 \pm 0.19$ \\
\hline T7 & $1014.4 \pm 19.1^{\mathrm{b}}$ & $72.38 \pm 4.55^{\mathrm{a}}$ & $1.79 \pm 0.2$ & $1.75 \pm 0.09$ & $0.23 \pm 0.08$ & $1.66 \pm 0.08$ \\
\hline T8 & $768.3 \pm 16.4^{\mathrm{d}}$ & $62.13 \pm 0.95^{\mathrm{c}}$ & $1.68 \pm 0.4$ & $2.64 \pm 0.69$ & $0.19 \pm 0.02$ & $1.68 \pm 0.15$ \\
\hline T9
\end{tabular}

(T1) Basal diet + Fenugreek powder $(1 \mathrm{~g} / \mathrm{Kg})$, (T2) basal diet + cinnamon powder $(1 \mathrm{~g} / \mathrm{Kg})$,

(T3) basal diet + fennel powder $(1 \mathrm{~g} / \mathrm{Kg})$, (T4) basal diet + anise powder (1 g/Kg), (T5) basal diet + equal mixture of the previous additives $(0.5 \mathrm{~g} / \mathrm{Kg})$. (T6) basal diet + equal mixture of the previous additives $(1.0 \mathrm{~g} / \mathrm{Kg})$, (T7) basal diet + equal mixture of the previous additives $(1.5 \mathrm{~g} / \mathrm{Kg})$, (T8) basal diet + equal mixture of the previous additives $(2.0 \mathrm{~g} / \mathrm{Kg})$ and (T9) fed basal diet without any supplementation (control).

Supplementation of fenugreek alone $(\mathrm{T} 1)$ increased $(\mathrm{P}<0.05)$ absolute carcass weight $(1082.9 \mathrm{~g})$ than the other treatments. While, the carcass percentage was superior significantly $(\mathrm{P}<0.05)$ for the chicks fed diet supplemented with fenugreek alone (T1) and $2.0 \mathrm{~g}$ mixture/ $\mathrm{Kg}$ diet (T8) as compared to the other treatments $(70.87 \%$ for $\mathrm{T} 1$ and $72.38 \%$ for $\mathrm{T} 8$, respectively). These results are combatable with the mentioned results of $B W$ and BWG. However, there were no significant differences among the percentages of birds gizzard, liver, spleen and testes weight due to the different supplementations. Adding the thyme or fennel to broiler diets had no 
significant effects on relative weights of liver, spleen, bursa of fabricius, thymus gland or intestine (Tollba, 2003).

\section{4-Blood biochemical and hematology traits:-}

The results indicated that all blood constituents were significantly influenced by experiment supplementations, as except that of AST, there was no significant effect of feed supplementation on it. (Tables 4 and 5). Supplementation of fenugreek, cinnamon and fennel alone (T1, T2 and T3) and 0.5 and $1.0 \mathrm{~g}$ mixture $/ \mathrm{Kg}$ diet $(\mathrm{T} 5$ and $\mathrm{T} 6)$ increased $(\mathrm{P}<0.05)$ total plasma protein than the other treatments (Table 4). While, supplementation of anise alone (T4) or 1.5 and $2.0 \mathrm{~g}$ mixture/ $\mathrm{Kg}$ diet (T7 and T8) decreased significantly total plasma protein and were approximately equal to that of control group (T9). Also, supplementation of fenugreek, cinnamon and fennel alone (T1, T2 and T3) increased significantly total plasma albumin (3.0, 2.9, $2.8 \mathrm{~g} / \mathrm{dL}$, respectively). Besides supplementations of 0.5 and $1.0 \mathrm{~g}$ mixture $/ \mathrm{Kg}$ diet (T5 and T6) increased significantly $(P<0.05)$ total plasma globulin compared to the other treatments.

Table (4): Effect of different medicinal plants supplementations on some blood biochemical traits.

\begin{tabular}{|c|c|c|c|c|c|c|}
\hline \multirow{2}{*}{$\begin{array}{c}\text { Feed } \\
\text { supplementation }\end{array}$} & $\begin{array}{c}\text { Total } \\
\text { Protein } \\
\text { (g/dl) }\end{array}$ & $\begin{array}{c}\text { Total } \\
\text { Albumin } \\
(\mathbf{g} / \mathbf{d l})\end{array}$ & $\begin{array}{c}\text { Total } \\
\text { Globulin } \\
(\mathbf{g} / \mathbf{d l})\end{array}$ & $\begin{array}{c}\text { Total } \\
\text { Cholesterol } \\
(\mathbf{m g} / \mathbf{d l})\end{array}$ & $\begin{array}{c}\text { AST } \\
\text { (U/L) }\end{array}$ & $\begin{array}{c}\text { ALT } \\
(\mathbf{U} / \mathbf{L})\end{array}$ \\
\hline T1 & $5.9 \pm 1.0^{\mathrm{a}}$ & $3.0 \pm 0.3^{\mathrm{a}}$ & $2.9 \pm .4^{\mathrm{b}}$ & $86.8 \pm 1.9^{\mathrm{b}}$ & $38.0 \pm 1.3$ & $16.2 \pm 0.8^{\mathrm{b}}$ \\
\hline T2 & $5.6 \pm 0.9^{\mathrm{a}}$ & $2.9 \pm 0.2^{\mathrm{a}}$ & $2.7 \pm 0.9^{\mathrm{c}}$ & $89.0 \pm 2.0^{\mathrm{b}}$ & $39.0 \pm 0.8$ & $16.6 \pm 1.0^{\mathrm{b}}$ \\
\hline T3 & $5.9 \pm 0.6^{\mathrm{a}}$ & $2.8 \pm 0.1^{\mathrm{a}}$ & $3.1 \pm 0.6^{\mathrm{b}}$ & $88.0 \pm 2.2^{\mathrm{b}}$ & $38.4 \pm 0.6$ & $15.7 \pm 1.4^{\mathrm{b}}$ \\
\hline T4 & $4.9 \pm 0.4^{\mathrm{b}}$ & $2.2 \pm 0.3^{\mathrm{b}}$ & $2.7 \pm 0.8^{\mathrm{c}}$ & $80.0 \pm 0.2^{\mathrm{c}}$ & $39.3 \pm 0.7$ & $14.0 \pm 1.1^{\mathrm{c}}$ \\
\hline T5 & $5.8 \pm 0.5^{\mathrm{a}}$ & $2.1 \pm 0.4^{\mathrm{b}}$ & $3.7 \pm 0.7^{\mathrm{a}}$ & $80.2 \pm 0.3^{\mathrm{c}}$ & $39.2 \pm 0.4$ & $14.3 \pm 0.2^{\mathrm{c}}$ \\
\hline T6 & $5.8 \pm 0.7^{\mathrm{a}}$ & $2.3 \pm 0.2^{\mathrm{b}}$ & $3.5 \pm 0.7^{\mathrm{a}}$ & $81.1 \pm 1.0^{\mathrm{c}}$ & $37.1 \pm 0.3$ & $13.2 \pm 0.3^{\mathrm{c}}$ \\
\hline T7 & $4.9 \pm 0.3^{\mathrm{b}}$ & $2.3 \pm 0.7^{\mathrm{b}}$ & $2.6 \pm 0.4^{\mathrm{c}}$ & $81.0 \pm 0.8^{\mathrm{c}}$ & $37.2 \pm 1.0$ & $13.0 \pm 1.1^{\mathrm{c}}$ \\
\hline T8 & $4.6 \pm 0.1^{\mathrm{b}}$ & $2.1 \pm 0.2^{\mathrm{b}}$ & $2.5 \pm 0.2^{\mathrm{c}}$ & $80.1 \pm 0.39^{\mathrm{c}}$ & $39.3 \pm 0.78$ & $13.9 \pm 1.3^{\mathrm{c}}$ \\
\hline T9 & $4.9 \pm 0.4^{\mathrm{b}}$ & $2.3 \pm 0.1^{\mathrm{b}}$ & $2.6 \pm 0.4^{\mathrm{c}}$ & $99.4 \pm 4.69^{\mathrm{a}}$ & $40.1 \pm 0.7$ & $20.0 \pm 0.5^{\mathrm{a}}$ \\
\hline
\end{tabular}

\& Column means with different superscripts are differ significantly $(P<0.05)$

AST = Aspartate transaminase, ALT = Alanine transaminase.

(T1) Basal diet + Fenugreek powder $(1 \mathrm{~g} / \mathrm{Kg})$, (T2) basal diet + cinnamon powder (1 $\mathrm{g} / \mathrm{Kg}$ ), (T3) basal diet + fennel powder (1 g/Kg), (T4) basal diet + anise powder (1 g/Kg), (T5) basal diet + equal mixture of the previous additives $(0.5 \mathrm{~g} / \mathrm{Kg})$. (T6) basal diet + equal mixture of the previous additives $(1.0 \mathrm{~g} / \mathrm{Kg}),(\mathrm{T} 7)$ basal diet + equal mixture of the previous additives $(1.5 \mathrm{~g} / \mathrm{Kg})$, (T8) basal diet + equal mixture of the previous additives $(2.0 \mathrm{~g} / \mathrm{Kg})$ and (T9) fed basal diet without any supplementation (control).

Data in Table (4), showed that total supplementation of medicinal plants alone or in the mixture form at any levels decreased significantly cholesterol and the level of ALT in blood plasma compared to control group. However, supplementation of anise alone or the mixture form of the medicinal plants at any levels (T4, T5, T6, T7 and T8) decreased significantly total cholesterol and ALT than the other treatments. No significant effect of food supplementation were found in the level of AST in blood plasma.

The results in Table (5) show that PVC\%, $\mathrm{Hg} \%$ and RBC counts were significantly influenced by feed supplementations which used. The highest percentages of blood hematology traits were recorded for the birds 
fed basal diet supplemented with $1 \mathrm{~g}$. anise $/ \mathrm{kg}$ diet (T5) and those fed $2.0 \mathrm{~g}$ mixture $/ \mathrm{kg}$ diet (T8). However, the lowest percentages of PCV\%, $\mathrm{Hg} \%$ and RBC counts were recorded for control group (T9). These results agree with those reported by El-Shobaki et al. (1990) who reported that anise promoted the absorption of iron. A majority of fenugreek enhanced the activity of pancreatic lipase and amylase when they are directly in contact with the enzyme (Ramakrishna et al. 2003). The used of fenugreek was reported to improve health and immunity in poultry (El-Mallah et al., 2005), also, induce hypo-cholesterolemia in poultry (El-Mallah et al. 2005). Studies have revealed that fennel contains powerful active components that might be effective for increasing human health and preventing cancer (Esiyok et al, 2004). Plasma cholesterol and total lipids were decreased for groups fed thyme or fennel compared with control groups under normal or high temperature conditions (Tollba and Hassan, 2003). The results consistence with what reported by Abaza (2001) in broiler chicks and Ghazalah et al., (1996) who stated that, supplementation ducks diet with thyme oil decreased the blood total lipids and total cholesterol concentration than control.

Table (5): Effect of different medicinal plants supplementations on PCV (\%), $\mathrm{Hg}(\%)$ and $\mathrm{RBCs}\left(10^{3} / \mathrm{mm}^{3}\right)$.

\begin{tabular}{|c|c|c|c|}
\hline \multirow{2}{*}{$\begin{array}{c}\text { Feed } \\
\text { supplementation }\end{array}$} & \multicolumn{3}{|c|}{ Blood hematology traits } \\
\cline { 2 - 4 } & PCV (\%) & Hg (\%) & RBCs $\left(\mathbf{1 0} \mathbf{m m}^{\mathbf{3}}\right)$ \\
\hline T1 & $43.9 \pm 0.8^{\mathrm{bc}}$ & $10.9 \pm 0.9^{\mathrm{a}}$ & $3.9 \pm 1.0^{\mathrm{b}}$ \\
\hline T2 & $44.3 \pm 0.9^{\mathrm{bc}}$ & $10.7 \pm 1.0^{\mathrm{a}}$ & $4.1 \pm 0.7^{\mathrm{b}}$ \\
\hline T3 & $45.7 \pm 1.2^{\mathrm{b}}$ & $10.6 \pm 0.5^{\mathrm{a}}$ & $3.9 \pm 0.3^{\mathrm{b}}$ \\
\hline T4 & $48.8 \pm 2.0^{\mathrm{a}}$ & $11.2 \pm 1.1^{\mathrm{a}}$ & $4.7 \pm 0.2^{\mathrm{a}}$ \\
\hline T5 & $43.0 \pm 0.7^{\mathrm{bc}}$ & $10.8 \pm 0.7^{\mathrm{a}}$ & $4.0 \pm 0.6^{\mathrm{b}}$ \\
\hline T6 & $46.8 \pm 0.8^{\mathrm{a}}$ & $10.9 \pm 0.4^{\mathrm{a}}$ & $3.8 \pm 0.5^{\mathrm{b}}$ \\
\hline T7 & $47.9 \pm 1.1^{\mathrm{a}}$ & $10.1 \pm 0.6^{\mathrm{a}}$ & $3.6 \pm 0.8^{\mathrm{b}}$ \\
\hline T8 & $48.7 \pm 1.9^{\mathrm{a}}$ & $11.0 \pm 1.1^{\mathrm{a}}$ & $4.6 \pm 0.4^{\mathrm{a}}$ \\
\hline T9 & $40.3 \pm 0.9^{\mathrm{c}}$ & $8.53 \pm 0.9^{\mathrm{b}}$ & $2.3 \pm 0.5^{\mathrm{c}}$ \\
\hline
\end{tabular}

\& Column means with different superscripts are differ significantly $(P<0.05)$

PCV = Packed cell volume, $\mathrm{Hg}=$ Hemoglobin concentration, $\mathrm{RBC}=$ Red blood cells (T1)

Basal diet + Fenugreek powder $(1 \mathrm{~g} / \mathrm{Kg})$, (T2) basal diet + cinnamon powder $(1 \mathrm{~g} / \mathrm{Kg})$,

(T3) basal diet + fennel powder $(1 \mathrm{~g} / \mathrm{Kg})$, (T4) basal diet + anise powder $(1 \mathrm{~g} / \mathrm{Kg})$, (T5) basal diet + equal mixture of the previous additives $(0.5 \mathrm{~g} / \mathrm{Kg})$. (T6) basal diet + equal mixture of the previous additives $(1.0 \mathrm{~g} / \mathrm{Kg}),(\mathrm{T} 7)$ basal diet + equal mixture of the previous additives $(1.5 \mathrm{~g} / \mathrm{Kg})$, (T8) basal diet + equal mixture of the previous additives $(2.0 \mathrm{~g} / \mathrm{Kg})$ and $(\mathrm{T9})$ fed basal diet without any supplementation (control).

\section{5-Microbiological Study:-}

Effects of using medicinal plant supplementation, separately or in a mixture form on the intestinal microbial counts are shown in Table 6 . The total aerobic and anaerobic counts and the counts of total coliform had been decreased due to supplementation of basal diet with medicinal plants as compared to control (T9). The greatest reduction was observed with the chicks fed on the basal diet supplemented by medicinal plants in a mixture form. These results were in agreement with several investigators used medicinal plants as feed additives. Cowan (1999) reported that plants are rich in a wide variety of secondary metabolites have antimicrobial properties. Also, Abdo et al. (2003) and 
Soliman et al.(2003) indicated that the populations of total microbial counts and the counts of total coliform and yeasts microbial on the broiler gastrointestinal tract were decreased due to increasing the level of different additives ( red pepper and marjoram)

Table (6): Effect of different medicinal plants supplementations on count of aerobic, anaerobic and total coliform bacteria in intestine

\begin{tabular}{|c|c|c|c|}
\hline Type of bacteria & $\begin{array}{c}\text { Aerobic plate } \\
\text { count }\end{array}$ & $\begin{array}{c}\text { Total coliform } \\
\text { Count }\end{array}$ & $\begin{array}{c}\text { Total anaerobic } \\
\text { count }\end{array}$ \\
\hline T1 & $14 \times 10^{3}$ & $30 \times 10^{4}$ & $5 \times 10^{1}$ \\
\hline T2 & $12 \times 10^{3}$ & $23 \times 10^{3}$ & $4 \times 10^{1}$ \\
\hline T3 & $4 \times 10^{2}$ & $21 \times 10^{3}$ & $3 \times 10^{1}$ \\
\hline T4 & $10 \times 10^{4}$ & $14 \times 10^{4}$ & $4 \times 10^{1}$ \\
\hline T5 & $8 \times 10^{2}$ & $12 \times 10^{2}$ & $-\mathrm{ve}$ \\
\hline T6 & $9 \times 10^{1}$ & $5 \times 10^{2}$ & $-\mathrm{ve}$ \\
\hline T8 & $2 \times 10^{1}$ & $6 \times 10^{1}$ & $-\mathrm{ve}$ \\
\hline T9 & $2 \times 10^{1}$ & $12 \times 10^{1}$ & $-\mathrm{ve}$ \\
\hline
\end{tabular}

(T1) Basal diet + Fenugreek powder (1 g/Kg), (T2) basal diet + cinnamon powder (1 g/Kg) (T3) basal diet + fennel powder $(1 \mathrm{~g} / \mathrm{Kg})$, (T4) basal diet + anise powder $(1 \mathrm{~g} / \mathrm{Kg})$, (T5) basal diet + equal mixture of the previous additives $(0.5 \mathrm{~g} / \mathrm{Kg})$. (T6) basal diet + equal mixture of the previous additives $(1.0 \mathrm{~g} / \mathrm{Kg}),(\mathrm{T} 7)$ basal diet + equal mixture of the previous additives $(1.5 \mathrm{~g} / \mathrm{Kg})$, (T8) basal diet + equal mixture of the previous additives $(2.0 \mathrm{~g} / \mathrm{Kg})$ and $(\mathrm{T9})$ fed basal diet without any supplementation (control).

\section{6-Liver and intestinal DNA:-}

Liver, duodenum, jejunum and ileum DNA concentration ( $\mathrm{mg} / \mathrm{g}$. tissue) were significantly affected by feed supplementation of medicinal plants (Table 7).

Table (7): Effect of different treatments on DNA concentration $(\mathrm{mg} / \mathrm{g}$ tissue) of liver and intestine (Duodenum, Jejunum and ileum) for Gimmizah cocks

\begin{tabular}{|c|c|c|c|c|}
\hline \multirow{2}{*}{$\begin{array}{c}\text { Feed } \\
\text { supplementation }\end{array}$} & \multicolumn{4}{|c|}{ DNA concentration (mg/g tissue) } \\
\cline { 2 - 5 } & Liver & Duodenum & Jejunum & Ileum \\
\hline T1 & $6.99 \pm 0.6^{\mathrm{a}}$ & $10.09 \pm 0.1^{\mathrm{a}}$ & $14.35 \pm 0.8^{\mathrm{a}}$ & $20.60 \pm 0.2^{\mathrm{a}}$ \\
\hline $\mathrm{T} 2$ & $4.23 \pm 0.9^{\mathrm{b}}$ & $10.75 \pm 0.7^{\mathrm{a}}$ & $10.82 \pm 0.2^{\mathrm{c}}$ & $9.74 \pm 0.3^{\mathrm{c}}$ \\
\hline T3 & $4.19 \pm 0.8^{\mathrm{b}}$ & $10.22 \pm 0.5^{\mathrm{a}}$ & $10.62 \pm 0.3^{\mathrm{c}}$ & $9.77 \pm 0.7^{\mathrm{c}}$ \\
\hline $\mathrm{T} 4$ & $4.02 \pm 0.5^{\mathrm{b}}$ & $10.89 \pm 0.8 \mathrm{~b}^{\mathrm{a}}$ & $10.25 \pm 0.6^{\mathrm{c}}$ & $9.73 \pm 0.5^{\mathrm{c}}$ \\
\hline $\mathrm{T} 5$ & $3.44 \pm 0.2^{\mathrm{bc}}$ & $7.58 \pm 0.2^{\mathrm{bc}}$ & $9.90 \pm 0.5^{\mathrm{c}}$ & $8.93 \pm 0.7^{\mathrm{cd}}$ \\
\hline T6 & $3.98 \pm 0.8^{\mathrm{b}}$ & $8.00 \pm 0.8^{\mathrm{b}}$ & $9.82 \pm 0.7^{\mathrm{c}}$ & $9.52 \pm 0.5^{\mathrm{c}}$ \\
\hline $\mathrm{T} 7$ & $4.31 \pm 0.5^{\mathrm{b}}$ & $8.60 \pm 0.5^{\mathrm{b}}$ & $9.92 \pm 0.8^{\mathrm{c}}$ & $9.75 \pm 0.1^{\mathrm{c}}$ \\
\hline T8 & $6.39 \pm 0.2^{\mathrm{a}}$ & $8.62 \pm 0.6^{\mathrm{b}}$ & $12.15 \pm 0.5^{\mathrm{b}}$ & $12.92 \pm 0.4^{\mathrm{b}}$ \\
\hline T9 & $3.14 \pm 0.9^{\mathrm{c}}$ & $7.05 \pm 0.9^{\mathrm{c}}$ & $9.94 \pm 0.7^{\mathrm{c}}$ & $8.61 \pm 0.9^{\mathrm{d}}$ \\
\hline
\end{tabular}

\& Column means with different superscripts are differ significantly $(P<0.05)$.

(T1) Basal diet + Fenugreek powder (1 g/Kg), (T2) basal diet + cinnamon powder $(1 \mathrm{~g} / \mathrm{Kg})$, (T3) basal diet + fennel powder $(1 \mathrm{~g} / \mathrm{Kg})$, (T4) basal diet + anise powder $(1 \mathrm{~g} / \mathrm{Kg})$, (T5) basal diet + equal mixture of the previous additives $(0.5 \mathrm{~g} / \mathrm{Kg}$ ). (T6) basal diet + equal mixture of the previous additives $(1.0 \mathrm{~g} / \mathrm{Kg}),(\mathrm{T} 7)$ basal diet + equal mixture of the previous additives $(1.5 \mathrm{~g} / \mathrm{Kg})$, (T8) basal diet + equal mixture of the previous additives $(2.0 \mathrm{~g} / \mathrm{Kg})$ and (T9) fed basal diet without any supplementation (control). 
The DNA concentration were significantly greater for both birds fed basal diet supplemented with fenugreek $(6.99,10.09,14.35$ and $20.6 \mathrm{mg} / \mathrm{g}$ tissue respectively) or those fed basal diet supplemented with $2.0 \mathrm{~g}$ mixture $/ \mathrm{kg}$ diet (6.39, 8.62, 12.15 and $12.92 \mathrm{mg} / \mathrm{g}$ tissue, respectively) than the other treatments. The lowest liver, jejunum and ileum DNA concentration was detected for control group (T9). Birds fed basal diet supplemented with individual medicinal plants (T1, T2, T3 and T4) had significantly higher duodenum DNA concentration than those fed the other treatments. The lowest duodenum DNA concentration was detected for control group (T9). These results associated and compatible with the results of BW and BWG, since the highest birds BW and BWG had the highest liver, jejunum and ileum DNA concentration and vice versa. Medicinal plants protect liver and intestinal tissue from damage and degradation, so that its metabolic function increased. Large body size has been found to be positively correlated with increased numbers of muscle cells (Smith, 1963; Lepore et al. 1965). DNA concentration is associated with genetic increases in BW (Lepore et al., 1965 and Fowler et al., 1980). Palo et al., (1995) found that total DNA, protein : DNA and RNA : DNA ratios of livers and jejunums were determined as indices of changes in cell size and number, also they reported that reduction of liver and jejunum cell number decrease total organ DNA.

\section{7-Economical efficiency:-}

The EE and REE values of different supplementations are summarized in Table 8. However, supplementation of medicinal plants as in individual or in mixture were form to chick basal diet increased the EE. Generally, the best EE was recorded for the birds fed basal diet supplemented with medicinal plants in mixture form at levels $2 \mathrm{~g} / \mathrm{Kg}$ diet (T8)and $1.5 \mathrm{~g} / \mathrm{Kg}$ diet (T7), which recorded $0.375,0.296$, respectively.

Table (8): Economical efficiency (E.E.) and relative economical efficiency (R.E.E.) estimated for different dietary supplementation

\begin{tabular}{|c|c|c|c|c|c|}
\hline \multirow{2}{*}{$\begin{array}{c}\text { Feed } \\
\text { supplementation }\end{array}$} & BW $^{(\mathbf{1})}$ & T. Rev/ .bird (2) & T. F. cost $^{(\mathbf{3})}$ & $\begin{array}{c}\text { Net Rev. / } \\
\text { bird }^{(4)}\end{array}$ & E.E $^{(\mathbf{5})}$ \\
\cline { 2 - 6 } & $\boldsymbol{g}$ & L.E. & L.E. & L.E. & \\
\hline T1 & 1411.6 & 11.999 & 9.919 & 2.08 & 0.210 \\
\hline T2 & 1227.8 & 10.436 & 8.916 & 1.52 & 0.171 \\
\hline T3 & 1215.9 & 10.336 & 8.781 & 1.55 & 0.177 \\
\hline T4 & 1220.0 & 10.390 & 8.935 & 1.44 & 0.161 \\
\hline T5 & 1123.3 & 9.547 & 7.489 & 2.06 & 0.275 \\
\hline T6 & 1200.1 & 10.201 & 8.232 & 1.93 & 0.239 \\
\hline T7 & 1217.1 & 10.345 & 7.983 & 2.36 & 0.296 \\
\hline T8 & 1284.3 & 10.917 & 7.939 & 2.98 & 0.375 \\
\hline T9 & 1122.1 & 9.538 & 8.889 & 0.65 & 0.073 \\
\hline
\end{tabular}




\section{REFERENCES}

Abaza I. M. (2001). The use of some medicinal plants as feed additives in broiler diets. Ph.D. thesis, Faculty of Agriculture, Alexandria, Univ., Alexandria, Egypt.

Abaza I. M. (2007). Effects of using fenugreek, chamomile and radish as feed additives on productive performance and digestibility coefficients of laying hens. Egypt. Poult. Sci., 27:199-218.

Abd El-Latif, S. A.; Faten, A.A.; and El-Kaiaty, A.M. (2002). Effect of feeding dietary thyme, black cumin. Dianthusand, fennel on productive and some metabolic responses of growing Japanese quail. Egypt. Poult. Sci., 22(1): 106-125.

Abdel-Malak, N. Y.; Abdel-Malak, M. S.; El-Gendi, G. M.; and Emily, F., Naguib (1995). Effect of feeding different levels of herbal feed additive on broiler performance in relation to some metabolic functions. Egypt. Poult. Sci., 15: $111-139$.

Abdo, Zeinab, M. A.; Soliman, A. Z. M.; and Barakat, Olfat S. (2003). Effect of hot pepper and marjoram as feed additives on the growth performance and the microbial population of the gastrointestinal tract of broilers. Egypt. Poult. Sci. 23: 91-113.

American Public Health Association (1985). Standard Methods for the Examination of Water and Wastewater, 16th Ed. APHA, Washington, D.C.

Burton, K. (1968). Determination of DNA concentration with diphenylamine. Pages 163-166 in Enzymology. Vol.3 L. Grossman and K. Moldave, ed. Academic Press Inc., New York, NY.

Cowan, M.M. (1999). Plant products as antimicrobial agents. Clinical Microbiology Reviews, Vol. 12, No. 4, 564-582.

Duncan, D. B. (1955). Multiple range and multiple F-Test. Biometrics 11:1-42.

Eilers, R.I. (1967). Notification of final adaptation of an international method and standard solution for hemoglobinometry specifications for preparation of standard solution. Am. J. Clin. Pathol. 47: 212-314.

EL- Mallah, G. M; Ibrahim, Sh. A. M. and Abdo Zeinab M. A. (2005). Garlic and fenugreek as feed addatives to different levels of protein and energy in diets of growing turkeys. Egypt. Poult. Sci. 25: 911-929.

El-Shobaki, F.A.; Saleh, Z.A. and Saleh, N. (1990).The effect of some beverage extracts on intestinal iron absorption. Z Ernahrungswiss. 29(4):264-269.

Esiyok, D.; Otles, S. and Akcicek, E. (2004). Herbs as a food source in Turkey. Asian Pac J .Cancer Prev. 5(3):334-9.

Fowler, S.P.; Campion, D.R.; Marks, H. L. and Reagan, J.O. (1980). An analysis of skeletal muscle response to selection for rapid growth in japanese quail ( Coturinix coturnix japanica). Growth 44:235-252.

Ghazalah, A.A.; and Faten, A.A., Ibrahim, (1996). The possibility of using some edible and aromatic oils in the nutrition of Muscovi Ducks. Egypt. Poult. Sci. 16(11): 305-328.

Greathead, H. (2003). Plants and plant extracts for improving animal productivity. Proc. Nutr. Soc. 62:279-290. 
Abdalla, A. A. et al.

Hassan, I., Abdallah, A.G and Abo El-Wafa, S. (1996). Utilization of decorticoated local cottonseed meal in broiler diets. Egypt. Poult. Sci. 16: 31-49.

Hassan, I.I.; Askar, A.A.; and El-Shourbagy, G.A. (2004). Influence of some medicinal plants on performance, physiological and meat quality traits of broiler chicks. Egypt. Poult. Sci. 24(1): 247-266.

Ibrahim, M. R.; Abd El-Latif, M. S.; and El-Yamany, A. T. (1998). Effect of adding some natural growth promoters to broiler chicks diets on growth performance, digestibility and some metabolic functions. J. Agric. Sci., Mansoura Univ., 32(3): 1029-1037.

Kosalec, I.; Pepeljnjak, S., and Kustrak, D. (2005). Antifungal activity of fluid extract and essential oil from anise fruits (Pimpinella anisum L., Apiaceae). Acta Pharm. 55(4):377-85.

Kreydiyyeh, S.I.; Usta, J.; Knio, K.; Markossian, S. and Dagher, S. (2003). Anise seed oil increases glucose absorption and reduces urine output in the rat. Life Sci. 74(5):663-73.

Lepore, P.D.; Siegel, P.B.and Siegel, H. S. (1965). Nucleic acid composition of chicks and chick tissues from growth selection lines of White Rocks. Poult. Sci. 44:126-130.

Mazur, W.M.; Duke, J.A.; Wahala, K.; Rasku, S.; and Adlercreutz , H. (1998). Isoflavonoids and lignins in legumes: Nutritional and health aspects in human, J. Nutr. Biochemistry, 9: 193-200.

Mohan T. (2004). Pharmacological screening of some medicinal plants as antimicrobial and feed additives. MSc. Thesis, Faculty of Virginia. State University. USA.

Negussie, B. (1989). Observations on internationalization(Article in Swedish). Jordemodern. 102(3):88-90.

Quale, J.; Landman, M.D.; Zaman, M.M.; Burney, S., and Sathe, S. S. (1996). In vitro activity of Cinnamomum zeylanicum against azole resistant and sensitive Candida species and a pilot study of cinnamon for oral candidiasis. Am. J. Chin. Med. 24:103-109.

Palo, P.E; Jerry, L.S.; Javir, P.; Maria, F.S.; and Lluis, V. (1995). Effect of early nutrient restriction on broiler chickens. 1- Performance and development of the gastrointestinal tract. Poult. Sci. 74:88-101.

Ramakrishna, R.R; Platel, K.; Srinivasan, K. (2003). In vitro influence of spices and spice-active principles on digestive enzymes of rat pancreas and small intestine. Nahrung. 47(6):408-12.

Rao, P.U.; Sesikeran, B.; Rao, P.S.; Naidu, A.N.; Rao, V.V.; and Ramachandran, E.P. (1996). Short term nutritional and safety evaluation of fenugreek. Elsevier Science Inc. 16 (9): 1495-1505.

Rao P.U.; and Sharma, R.D. (1987). An evaluation of protein quality of fenugreek (Trigonella Foenum graecum L.) and their supplementary effects. Food Chemistry, 24: 1-9.

SAS Institute, Inc. (1990). SAS User's guide: Statistics. SAS Inst. Inc., Cary, NC.

Seiverd, E.C. (1964). HEMATOLOGY FOR MEDICAL TECHNOLOGY, 3 rd Edition, Lea and Febiger: Philadelphia. 
Shibko, S.; Koivistoinen, P.; Taratnyek, C.A.; Newhall, A.R.; and Friedman, L.L. (1967). A method for sequential quantitative separation and determination of protein, RNA, DNA, lipid and glycogen from a single rat liver homogenate or from a subcellular fraction. Anal. Biochem. 19:514-528.

Smith, J. H. (1963). Relation of body size to muscle cell size and number in the chicken. Poult. Sci. 42:283-290.

Soliman, A.Z.M.; Ali, M.A.; and Abdo, Z.M.A. (2003). Effect of marjoram, bactiracin and active yeast as feed additives on the performance and the microbial content of the broiler's intestinal tract. Egypt. Poult. Sci. 23: 445-467.

Tolba, A.A.H. (2003). Using some natural additives to improve physiological and productive performance of broiler chicks under high temperature conditions. 1- Thyme (Thymus vulgaris I.) or Fennel (Foniculum vulgare l.). Egypt. Poult. Sci. 23(II): 313-326).

Valero, M.; and Salmeron, M.C. (2003). Antibacterial activity of 11 essential oils against Bacillus cereus in tyndallized carrot broth. Int. J. Food Microbiol. 85:73-81.

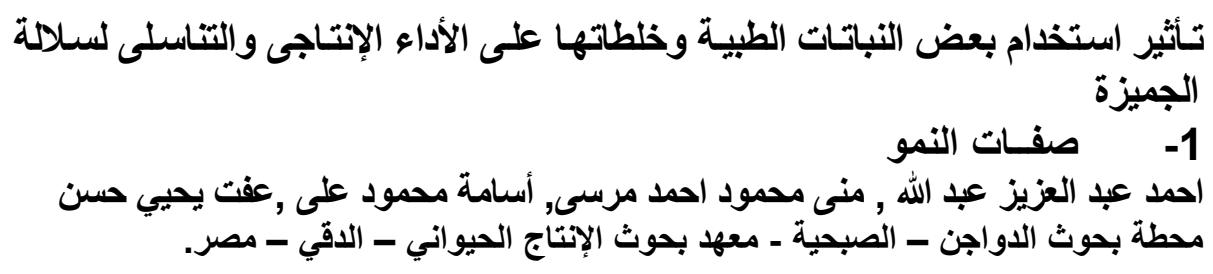

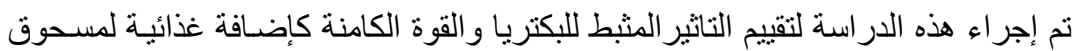

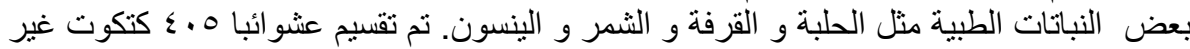

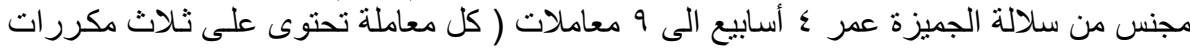

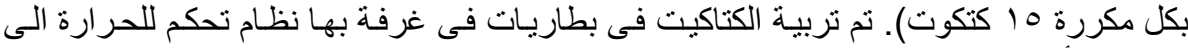

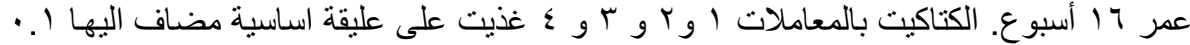

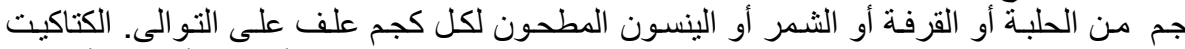

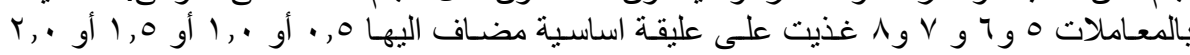

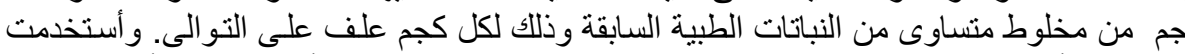

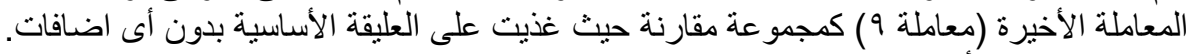

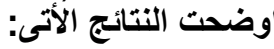

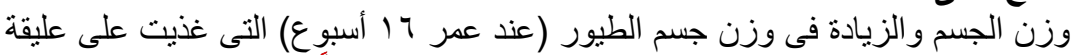

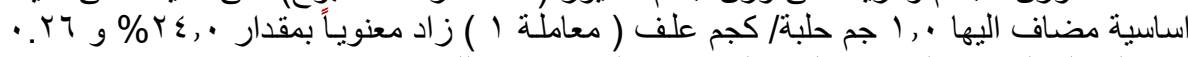

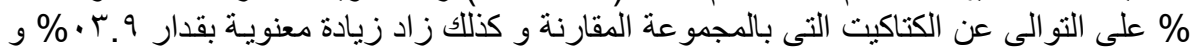

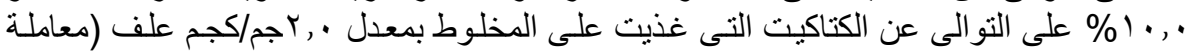

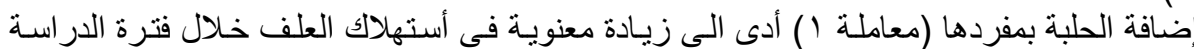

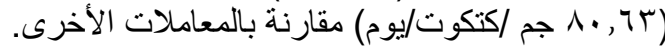

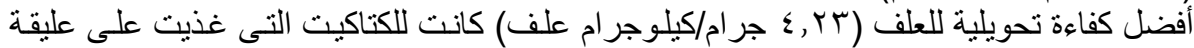

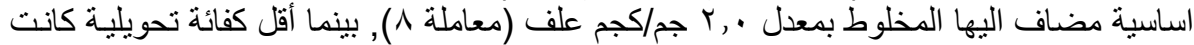

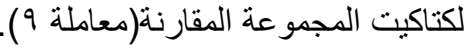

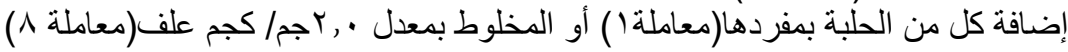

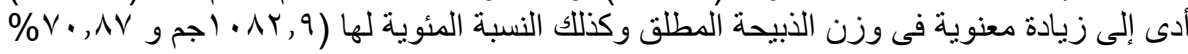




\section{Abdalla, A. A. et al.}

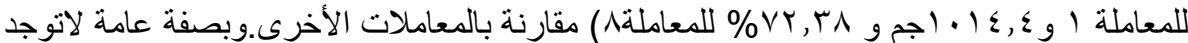

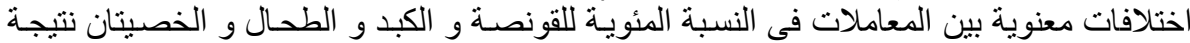

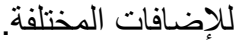

تركيز كلا من الكوليسترول الكلى و إنزيم Alanine transaminase في بلازما الدم ينخفضـان

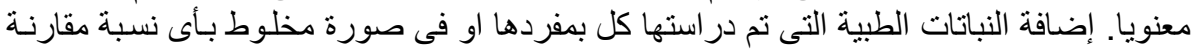

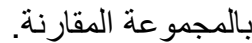
العدد الكلى للميكروبات الهو ائية و اللاهو ائية و أعداد بكتيريا القولون الكلية إنخفضت انخفاضـا

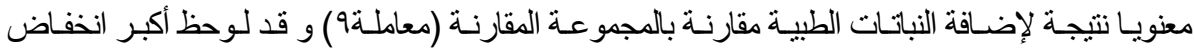

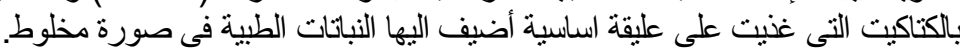

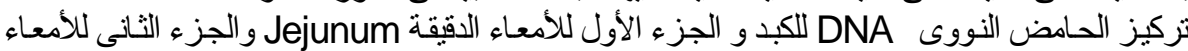

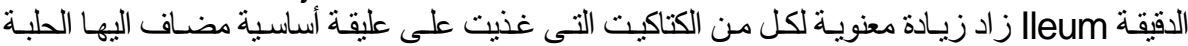

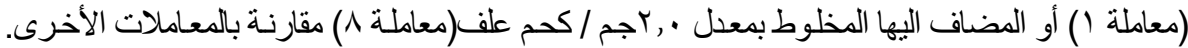

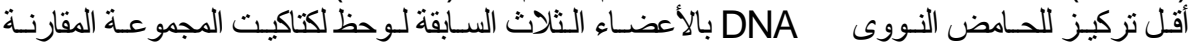

إضافة النباتات الطبية المستخدمة كل بمفردها أو فى صورة مخلوط للعليقة الأساسية لعلف العادية

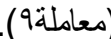

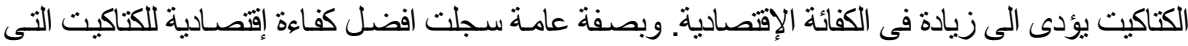

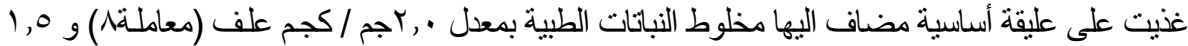

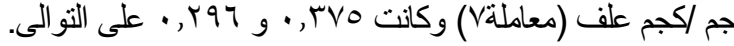

